\title{
Effects of Online Bookstores' Perceived Quality on Consumer Loyalty: Consumer Satisfaction as a Mediator (Note 1)
}

\author{
Feixiang Zhang ${ }^{1} \&$ Yang Yang ${ }^{2}$ \\ ${ }^{1}$ College of Communication, University of Shanghai for Science and Technology, Shanghai, China \\ ${ }^{2}$ Shanghai Publishing and Printing College, Shanghai, China \\ Correspondence: Feixiang Zhang, College of Communication, University of Shanghai for Science and Technology, \\ Shanghai, China.
}

Received: October 29, 2019

Accepted: November 14, 2019

Online Published: November 26, 2019

doi:10.5430/ijba.v10n6p32

URL: https://doi.org/10.5430/ijba.v10n6p32

\begin{abstract}
The paper adopts SPSS19.0 and AMOS20 to conduct an empirical study on the effects of e online bookstore perceived quality on consumer loyalty and the mediated effect of consumer satisfaction on the relationship, based on a 217 questionnaire data. The results show that online bookstore perceived quality does not have a significant positive effect on consumer loyalty; online bookstore perceived quality has a significant positive effect on online purchasing consumer satisfaction; online shopping consumer satisfaction has a significant positive effect on consumer loyalty; consumer satisfaction has a total mediating effect on the relationship between online bookstore perceived quality and customer loyalty and online bookstore perceived quality has a significant positive effect on consumer loyalty through consumer satisfaction. In order to fully play the mediating role of consumer satisfaction to improve the online bookstore consumer loyalty, the article puts forward related suggestions. The future research should expand the sample range and consider roles of other factors on the relationship.
\end{abstract}

Keywords: internet bookstore, e-loyalty, SEM, mediating effect

\section{Introduction}

With the rise of the Internet and e-commerce, consumers' shopping behavior has changed dramatically. Online shopping has gradually become consumers' daily consumption pattern, especially online shopping for books has become the most mainstream consumption patterns for book consumers. According to a survey, book sales in the domestic online bookstores has accounted for $95 \%$ in the sales of non-teaching book market[1]. Compared with the domestic monopoly of the brick-and-mortar bookstores, the internet environment allows consumers to easily and conveniently compare the products and services provided by the network bookstores and simply buy books or shift to other online bookstores by simply clicking the mouse. Therefore, there is hot competition between online bookstores. At present, market share of book sales in the three websites-Dangdang, Jingdong and Amazon is a situation of tripartite confrontation, which makes competition increasingly fierce. Consumer loyalty is often considered a magic weapon to succeed for the enterprise, and then, in the Internet environment, consumer loyalty is deemed as a key way to maintain the competitive advantage. According to the concept of consumer loyalty defined by the famous American scholar Oliver (1997), consumer loyalty in this paper refers to the consumers' behavior of long-time-repeated books purchasing in a network bookstore and his behavior of recommending the network bookstore to other consumers.

In the traditional service field, the study on the relationship between service quality, customer loyalty and customer satisfaction in the academic circle is more mature. For example, there is consumer satisfaction index model. In this model, service quality affects customer satisfaction and consumer satisfaction influences consumer loyalty. However, in the internet environment, especially for the online shopping behavior, scholars have not yet studied the intrinsic mechanism of effect of the perceived quality on consumer loyalty. Neither have the scholars verified the relationship between perceived quality, consumer satisfaction and consumer loyalty. This is the very focus of the discussion in the paper. 


\section{Research Hypothesis and Model}

\subsection{Research Hypothesis}

\subsubsection{Relationship Between Perceived Quality and Loyalty of Online Bookstore}

Oliver [2], a famous scholar in the United States, has made a pioneering contribution to the definition of consumer loyalty. He believes that consumer loyalty is the consumer's preference and attitude towards a particular enterprise, product and service and the consumer's actual repeated purchase behavior. According to the researches (Lam, 2004; Fullerton, 2005; Kumar \&Shah, 2006), consumer loyalty is mainly defined from two perspectives: behavior and attitude. From the perspective of behavior, consumer loyalty mainly refers to the consumers' repeated purchase or consumers' recommendation; from the perspective of attitude, it mainly refers to the consumer's preference for a particular enterprise or product. Consumer loyalty in the internet environment shares the same standpoint with the traditional consumer loyalty. Hsu et al (2013) said consumer loyalty is the consumers' attitude and behavior of repeated purchase in online stores.

Perceived quality of online bookstore refers to consumers' perceived service quality in online shopping, including online service quality and offline service quality. Petter et al (2013) believed that the perceived quality of online bookstore includes the accuracy of web-related information, and interactivity, ease of use, reliability and humanization of the system. Offline service quality refers to all the related services the online bookstores provide, including the return and exchange quality of goods and the logistics service quality and so on. A literature examining department stores shows that perceived service quality has a positive impact on consumer loyalty (Wong\& Sohal, 2003). To sum up, the following assumptions are put forward in the paper:

H1: Perceived quality of online bookstores has a significantly positive effect on consumer loyalty.

\subsubsection{The Mediating Effect of Customer Satisfaction on Perceived Quality of Online Bookstores and Consumer} Loyalty

Szymanski \& Hise (2000) defines consumer satisfaction as the overall perception of consumers' shopping experience on the Internet and the antecedents of online consumer satisfaction includes the convenience, accuracy of product information provided by the website, and website design and its security. The empirical results show that the online service quality including the convenience of the website, website design and its security has the significant positive effect on the online consumer satisfaction. Joong-Kun (2001) made an empirical research on the impact of the logistics of the online store in the internet environment on customer satisfaction, finding that the logistics capability and service level of the online store is very important for the improvement of customer satisfaction. To sum up, this paper puts forward the following assumptions:

$\mathrm{H} 2$ : Perceived quality of online bookstores has a significantly positive effect on consumer satisfaction of online shopping.

Consumer satisfaction is determined by the consumer's perception, which is an attitude caused after the consumer' purchase of a product or service. Consumer loyalty refers to the consumer identification with the company or repeated purchase behavior. A large number of studies show that consumer satisfaction is an important influencing factor to maintain consumer loyalty and to achieve long-term profitability of the enterprise (Bendapudi \& Berry, 1997). However, this relationship is not stable because of the competition in different industries. Loyal consumers are mostly satisfied, but it can not be predicted that the satisfied consumers are also loyal. In the automotive industry, about $90 \%$ of consumers are satisfied with the purchase of the car, but only about $40 \%$ of consumers have repeated purchase behavior (Reichheld, 1996). In the internet industry, most of the research shows that consumer satisfaction has a positive effect on consumer loyalty. Luarn (2003) found that consumer satisfaction is the main factor of influencing consumer loyalty in internet companies through empirical research of the online travel service companies and other enterprises. The study made by Kim\&Ferrin (2009)also found that online consumers will continue to use the online system as long as they are satisfied. To sum up, this paper puts forward the following assumptions:

H3: Consumer satisfaction of online bookstores has a significantly positive effect on consumer loyalty.

All in all, according to the above analysis, consumer satisfaction plays a mediating role in the effect of perceived quality of online bookstores on consumer loyalty. That is, in the process of consumer online shopping, consumers' perceived service quality of the online shopping influences consumers' repeated purchase behavior on the site through consumer satisfaction. Therefore, this paper puts forward the following assumptions:

H4: Consumer satisfaction has a mediating effect on the relationship between perceived quality of online bookstores and customer loyalty. 


\subsection{Hypothesis Model}

According to the above analysis and hypothesis, combined with the previous research, this paper puts forward the following theoretical model and the hypothesized relationship diagram, as shown in Figure 1:

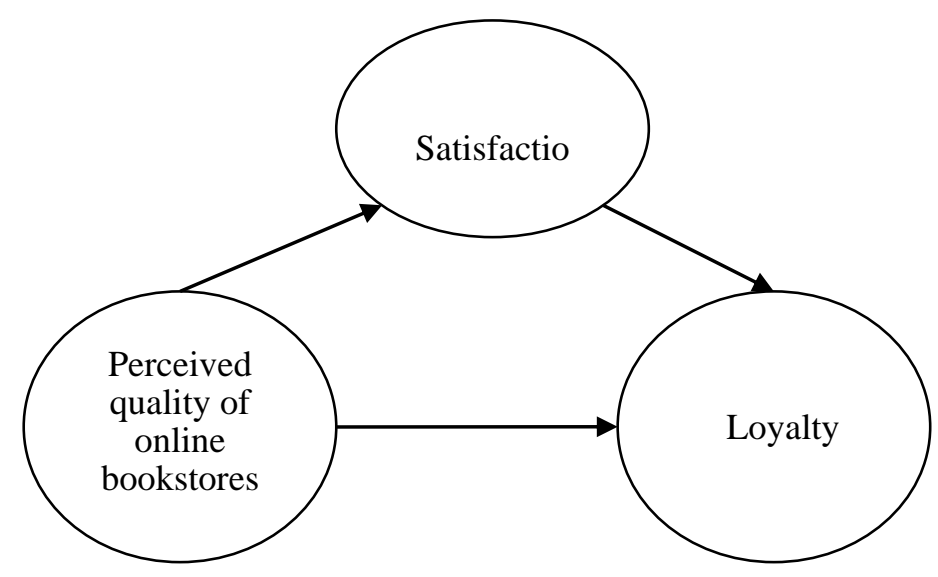

Figure 1. Theoretical model of the research

\section{Questionnaire Design and Data Collection}

\subsection{Questionnaire Design}

Based on the theoretical model of the research and the reference of previous research, items of observation variables which should be included in the questionnaire were made a preliminary and the initial scale was got. Before the formal investigation, a pre-test in a small range was made and the semantic meaning and context of the questionnaire were modified, eventually the questionnaire survey employed in the paper was formed. There are 3 potential variables in the research: consumer loyalty, consumer satisfaction, perceived quality of online bookstore. In order to ensure the reliability and validity of the measurement, this study used the scale of the existing literature, and made some modification according to the characteristics and purposes of the research. All items adopt 7-point Likert scale. The questionnaire items are shown in Table 1.

Table 1. Measurement items of potential variables and reliability test of questionnaire

\begin{tabular}{|c|c|c|c|c|}
\hline scale & & measurement items & $\begin{array}{l}\text { C ronbach's } \alpha \\
\text { coefficent }\end{array}$ & Source of items \\
\hline \multirow{5}{*}{$\begin{array}{l}\text { perceived } \\
\text { quality }\end{array}$} & Q1 & \multirow{5}{*}{$\begin{array}{l}\text { if it is convenient and reliable to purchase books } \\
\text { on the website; } \\
\text { if there are fake or poor goods on the shopping } \\
\text { website; } \\
\text { If the return or exchange service on the website } \\
\text { is convenient; } \\
\text { If offline logistics can offer timely delivery in } \\
\text { good condition. }\end{array}$} & \multirow{5}{*}{0.949} & \multirow{5}{*}{$\begin{array}{l}\text { Ranganathan \& } \\
\text { GanaPathy (2002) }\end{array}$} \\
\hline & Q2 & & & \\
\hline & Q3 & & & \\
\hline & $\mathrm{Q} 4$ & & & \\
\hline & & & & \\
\hline \multirow[t]{4}{*}{ loyalty } & Q5 & \multirow{4}{*}{$\begin{array}{l}\text { When I need to make a purchase of books, I will } \\
\text { think of the website first; } \\
\text { I often make a purchase of books on the online } \\
\text { bookstore; }\end{array}$} & \multirow{4}{*}{0.932} & \multirow{4}{*}{$\begin{array}{l}\text { Anderson } \quad \& \\
\text { Srinivasan }(2003)\end{array}$} \\
\hline & Q6 & & & \\
\hline & Q7 & & & \\
\hline & Q8 & & & \\
\hline
\end{tabular}




\begin{tabular}{|c|c|c|c|c|}
\hline & & $\begin{array}{l}\text { books; } \\
\text { I will mention the advantages of the online } \\
\text { bookstore to my friends. }\end{array}$ & & \\
\hline \multirow[t]{5}{*}{ satisfaction } & Q9 & \multirow{2}{*}{$\begin{array}{l}\text { I feel very happy when purchasing books from } \\
\text { online bookstores; }\end{array}$} & & \multirow[b]{3}{*}{ HaHong (2006) } \\
\hline & Q10 & & & \\
\hline & Q11 & \multirow{2}{*}{$\begin{array}{l}\text { My expectation can be met in the transaction } \\
\text { process of purchasing books on the website; } \\
\text { Books and services provided by the website can } \\
\text { meet my expectations; }\end{array}$} & & \\
\hline & Q12 & & 0.960 & \multirow[t]{2}{*}{$\begin{array}{l}\text { Balabanis et al. } \\
(2006)\end{array}$} \\
\hline & & $\begin{array}{l}\text { I feel very satisfied with my book purchasing on } \\
\text { the website. }\end{array}$ & & \\
\hline
\end{tabular}

\subsection{Data Collection}

Considering university teachers and students are the main subject of online books purchasing, the survey respondents are mainly focused on university teachers and students. At the same time, it is also considered that survey respondents should have a good online shopping experience, so this research questionnaires are distributed through the micro channel, micro blog, QQ and other social medias, and 279 copies of questionnaire are collected, and 217 effective copies of questionnaire are got after eliminating 62 unqualified copies of questionnaire, The recovery rate of effective copies is $77.8 \%$, which is in line with the requirements of adopting structural equation model analysis.

\section{Data Analysis and Results}

\subsection{Reliability Test}

In this paper, Cronbach's $\alpha$ is used to test the reliability of the questionnaire, and it is believed that the reliability coefficient of more than 0.7 is to be acceptable reliability. The reliability test in this paper analyzed by SPSS19.0 is shown in Table 1. Table 1 shows that the alpha coefficients of all the latent variables are more than 0.7, which indicates that the scale has good reliability, and the measurement indexes of each potential variable are reliable and have high internal consistency.

\subsection{Validity Test}

The validity of the scale is generally to examine convergent validity and discriminant validity. Factor analysis can be used to examine convergent and discriminant validity. Factor analysis of the scale of consumer loyalty model of network bookstores was made, and KMO value of 0.919 is more than the threshold of 0.7, and the Bartlett's test of the sample data is significant, which is suitable for the factor analysis of the observed variables.

After the above two tests, by using principal component analysis method and the Kaiser standard orthogonal rotation method, rotation becomes convergent after three iterations and the rotated factor loading table shown in Table 2 is got. All factor loadings of each observed variable are greater than 0.5 , the minimum acceptable level, which indicates that the measurement scale has a more significant discriminant validity.

Table 2. Rotated factor loading matrix table

\begin{tabular}{lllllll}
\hline item & Q1 & Q2 & Q3 & Q4 & Q5 & Q6 \\
\hline loading & 0.759 & 0.775 & 0.873 & 0.823 & 0.846 & 0.840 \\
\hline item & Q7 & Q8 & Q9 & Q10 & Q11 & Q12 \\
\hline loading & 0.820 & 0.821 & 0.741 & 0.880 & 0.853 & 0.863 \\
\hline
\end{tabular}

\subsection{Model Hypothesis Verification}

In this study, the relationship between latent variables and the relationship between latent variables and observed variables need to be observed and measured, so the structural equation model is very suitable for the empirical analysis of the theoretical model proposed in this study because the traditional statistical methods can not effectively deal with latent variables while the structural equation model can deal with latent variables and observed variables at 
the same time. The structural equation model software Amos20.0 is used to test each assumption in the model in this research. The structural equation model and its path coefficient are obtained by the analysis of the structure equation model and the path coefficient is shown in Figure 2. Table 3 test results of fitting degree of the model.

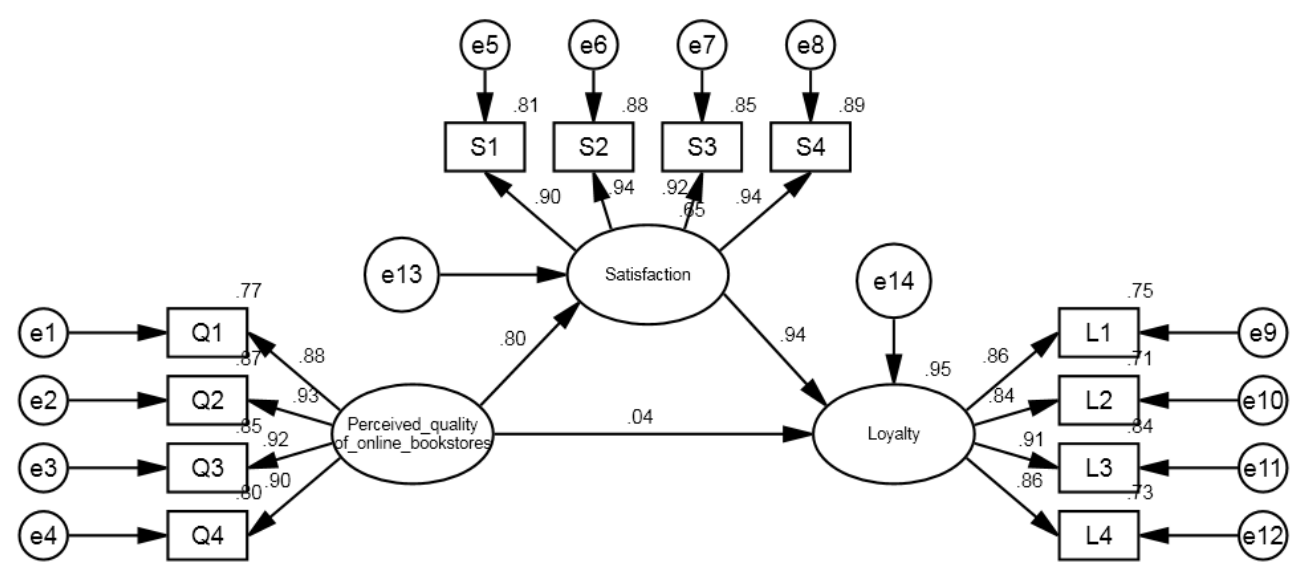

Figure 2. The result of SEM

Table 3. Goodness of fit test list for the model

\begin{tabular}{lllllll}
\hline Fitting index & $\chi^{2} / d f$ & CFI & NFI & GFI & AGFI & RMSEA \\
\hline Standard value & $<3$ & $>0.9$ & $>0.9$ & $>0.9$ & $>0.9$ & $<0.08$ \\
\hline Measured value & 2.67 & 0.96 & 0.94 & 0.95 & 0.90 & 0.053 \\
\hline
\end{tabular}

From the goodness of fit test list, it can be seen that the ratio of value of the Chi-square and the degree of freedom is 2.67, less than the threshold value of 3, and the fitting index of both GFI and AGFI is greater than the threshold value of 0.9, and RMSEA value is 0.053 which is less than the threshold value of 0.08 , and the relative fitting index of CFI and NFI is also more than the reference standard of 0.9. The fitting index mentioned above all meets the requirements, indicating the overall fitting degree of the structural equation model is better.

\subsection{Mediating Effect Test of Customer Satisfaction}

According to Baron and Kenny's mediating effect test method (1986), this study tests the mediating effect of consumer satisfaction on the relationship between online bookstores' perceived quality and consumer loyalty based on the following three steps. The first step is to explore the standardized regression coefficient of the direct effect of online bookstore perceived quality on consumer loyalty, which is treated as the dependent variable; the second step is to explore the standardized regression coefficient of the direct effect of online bookstore perceived quality on consumer satisfaction, which is treated as the dependent variable; the third step is to treat online bookstore perceived quality as independent variable, consumer satisfaction as mediating variable and consumer loyalty as dependent variable, exploring the influence path of independent and mediating variables on the dependent variable and constructing the standardized regression coefficient through the structural equation model .If the regression coefficient in the final step is still significant, there is the partial mediating effect, and if the regression coefficient of the independent variable is insignificant, there is a complete mediating effect. In this paper, the path coefficient shows that the effect of online bookstores' perceived quality on consumer loyalty is not significant with consumer satisfaction as mediating variable while the standardized coefficient between online bookstore perceived quality and consumer satisfaction is 0.80 , which supports assumption 2 ; and the standardized coefficient between consumer satisfaction and consumer loyalty is 0.94 , which supports the assumption 3 . This result proves that consumer satisfaction mediates the effect of online bookstores' perceived quality on consumer loyalty.

\section{Conclusion and Suggestion}

Based on the previous researches, this paper discusses the relationship between online bookstore perceived quality, 
customer satisfaction and customer loyalty, and tests the mediating effect of consumer satisfaction. The main conclusions of the study are: (1) online bookstores' perceived quality does not have a significant positive effect on consumer loyalty; (2) online bookstores' perceived quality has a significant positive effect on online shopping consumer satisfaction; (3) online (purchasing) shopping satisfaction has a significant positive effect on consumer loyalty; (4) consumer satisfaction has a total mediating effect on the relationship between online bookstore perceived quality and customer loyalty.

The conclusions in this paper have some managerial implications for improving the consumer loyalty of online bookstores. First, although the perceived quality of online bookstores has no direct significant effect on consumer loyalty, however, the perceived quality of online bookstores can have a significant positive impact on customer loyalty by means of consumer satisfaction as consumer satisfaction plays a mediating role in the relationship between perceived quality of online bookstores and customer loyalty. Therefore, it is very important to improve customers' satisfaction by constantly improving consumers' perceived quality of online bookstores so as to safeguard and promote the customers' loyalty. For better consumers' perceived quality, firstly, interactivity, ease of use and friendliness of online bookstore interface should be continuously bettered, and safety and reliability of the network system should be strengthened; secondly, (the good book) quality of online bookstores should be ensured and piracy and defective books cheating should be strictly avoided, and then consumers must be informed if there are some defective or second-hand books; thirdly, offline service quality must be strengthened and the logistics and distribution system should be perfected so as to ensure timely delivery of online purchased books without any damage; fourthly, offline communication should be promoted for better after-sales service such as return or exchange of products. Besides, consumer satisfaction can be enhanced by lowering consumer expectations as well as the perceived quality. When consumer expectations are very high, consumer satisfaction can not be high in spite of the very high online bookstore perceived quality. Therefore, it is necessary to lower consumer expectations to promote the satisfaction of online shopping. To lower consumer expectations, online bookstores should keep consumer from feeling deceived by well informing consumers of their service available and any possible problem in the process of online shopping.

There are some limitations in the research. Firstly, one is the research sample is mainly from university teachers and students in Shanghai and so the sample is to be further verified; secondly, the focus of this paper is consumer satisfaction has the mediating effect on the relationship between online bookstore perceived quality and consumer loyalty, but in the future research, trust, transfer cost and other factors can be introduced so as to further reveal the mechanism of consumer satisfaction on online bookstore perceived quality and consumer loyalty.

\section{References}

Anderson, R. E., Srinivasan, S. S., E-satisfaction, \& E-loyalty, (2003). A Contingency Framework. Psychology and Marketing, 20(2), 123-138. https://doi.org/10.1002/mar.10063

Balabanis, G., Reynolds, N., \& Simintiras, A. (2006). Bases of E-Store Loyalty: Perceived Switching Barriers and Satisfaction. Journal of Business Research, 59(2), 214. https://doi.org/10.1016/j.jbusres.2005.06.001

Baron, R. M., \& David, A. K. (1986). The Moderator Mediator Variable Distinction in Social Psychological Research: Conceptual, Strategic, and Statistical Considerations. Journal of Personality and Social Psychology, 51(6), 1173-1182. https://doi.org/10.1037/0022-3514.51.6.1173

Bendapudi, N., \& Berry, L. L. (1997). Customers' Motivations for Maintaining Relationships with Service Providers. Journal of Retailing, 73(1), 15-37. https://doi.org/10.1016/S0022-4359(97)90013-0

Cho, J. K. J. (2001). Firm Performance in the E-Commerce Market: The Role of Logistics Capabilities and Logistics Outsourcing. Doctoral Dissertation, University of Arkansas Fayetteville.

Fullerton. (2005). Compatibility Effects in Evaluations of Satisfaction and Loyalty. Journal of Economic Psychology, 26(1), 35-57. https://doi.org/10.1016/j.joep.2003.10.002

HaHong, Y. (2006). An Integrative Model of Consumer Satisfaction in the Context of E-Services. International Journal of Consumer Studies, 30(2), 137-149. https://doi.org/10.1111/j.1470-6431.2005.00458.x

Hsu, C. L., Wu, C. C., \& Chen, M. C. (2013). An Empirical Analysis of the Antecedents of E-Satisfaction and E-Loyalty: Focusing on the Role of Flow and Its Antecedents. Information Systems and e-Business Management, 11(2), 287-311. https://doi.org/10.1007/s10257-012-0194-8

Kim, D. J., Ferrin, D. L., \& Rao, H. R. (2009). Trust and Satisfaction, Two Stepping Stones for Successful E-Commerce Relationships: A Longitudinal Exploration. Information Systems Research, 20(2), 237-257. 
https://doi.org/10.1287/isre.1080.0188

Kumar, V., Shah, D., \& Venkatesan, R. (2006). Managing Retailer Profitability-One Customer at a Time. Journal of Retailing, 82(4), 277-294. https://doi.org/10.1016/j.jretai.2006.08.002

Lam, S. Y., Shankar, V., Erramilli, M. K., \& Murthy, B. (2004). Customer Value, Satisfaction, Loyalty, and Switching Costs: an Illustration from a Business-to-Business Service Context. Journal of the Academy of Marketing Science, 32(3), 293-311. https://doi.org/10.1177/0092070304263330

Luarn, P., \& Lin, H. H. (2003). A. Customer Loyalty Model for E-Service Context. Journal of Electronic Commerce Research, 4(4), 156-167.

Oliver, R. (1997). Satisfaction: A Behavioral Perspective on the Consumer. NewYork: The MeGraw-HillCom Panies.

Petter, S., DeLone, W., \& McLean, E. R. (2013). Information Systems Success: The Quest for the Independent Variables. Journal of Management Information Systems, 29(4), 7-61. https://doi.org/10.2753/MIS0742-1222290401

Ranganathan, C., \& Ganavathy, S. (2002). Key Dimensions of Business-to-Consumer Web sites. Information and Management, 39(6), 457-465. https://doi.org/10.1016/S0378-7206(01)00112-4

Reichheld, F. F. (1996). Learning from Customer Defections: The Customers You Lose Hold the Information You Need to Succeed. Harvard Business Review, 74(2), 61-70.

Study Report of Online Shopping Market in China. (2013). Retrieved from http://www.cnnic.net.cn/hlwfzyj/hlwxzbg/dzswbg/201404/t20140421_46598.htm

Szymanski, D. M., \& Hise, R. T. (2000). E-satisfaction: An Initial Examination. Journal of Retailing, 76(3), 309-322. https://doi.org/10.1016/S0022-4359(00)00035-X

Wong, A., \& Sohal, V. (2003). Service Quality and Customer Loyalty Perspectives on two Levels of Retail Relationships. Journal of Services Marketing, 17(5), 495-513. https://doi.org/10.1108/08876040310486285

\section{Note}

Note 1. Sponsored by Research Program of Humanities and Social Sciences by the Ministry of Education in China-Study on Models of Socialized Content Production of Digital Publishing and Its Management Mechanism (14YJA860001). 